\title{
The Use of Simulation Programmes for the Structural Analysis and Engineering Optimization of Gating System Structures for Use with High Pressure Die Casting Technology
}

Ján Majerník, Ján Kmec, Miroslav Gombár, Martin Podařil

Institute of Technology and Business in České Budějovice, Okružní 517/10, 370014 České Budějovice, Czech Republic, E-mail: majernik@mail.vstecb.cz

A properly designed and engineered gating system for use with high pressure die casting technology will produce castings with excellent mechanical properties. The gating system must secure the fast and continuous filling of the cavity. An appropriately designed and structured gating system can reduce the length of the die casting process, thereby increasing the effectiveness of production, reducing the amount of waste, and delivering cost savings. This article focuses on the structural analysis and optimization of runners and their impact on the mould casting of a specific light-weight casting made of AISi alloy.

Keywords: die casting, simulation analysis and modelling, optimalization

\section{References}

[1] MAJERNÍK, J. (2016). Výskum vplyvu konštrukčných úprav vtokového systému tlakovej formy na kvalitu odliatkov: Dizertačná práca. Prešov: Fakulta výrobných technológií so sídlom v Prešove, 2016

[2] PAŠKO, J., GAŠPÁR, Š. (2014). Technological factors of die casting. 1st ed. 2014. ISBN 978-3-942303-25-5

[3] GAŠPÁR, Š., PAŠKO, J. (2015). Technológia výroby hliníkových odliatkov tlakovým liatím. 1st ed. 2015. ISBN 978-80-553-2236-0

[4] MAJERNÍK, J., GERKOVÁ, J. (2014). Vplyv konštrukcie vtokového systému na kvalitu odliatkov. Posterus.sk, 2014, vol. 7, no. 8, p. 1-5. ISSN 1338-0087

[5] GAŠPÁR, Š., PAŠKO, J., MAJERNÍK, J. (2016). Specific Pressure and Mechanical Properties of the Alternator Flange from EN AC 47100 Alloy in HPDC Technology. TEM Journal, 2016, vol. 5, no. 2, p. 160-164. ISSN 22178309

[6] PAŠKO, J. (2010). Die Casting Plunger Pressing Velocity and Analysis of Its Influence on a Permanent Deformation Value of a Casting Made from an ENAC 47100 Alloy. MANUFACTURING TECHNOLOGY, 2010, vol. 10, p. 23-26. ISSN 1213-2489

[7] LIPIŃSKI, T. (2011). Use Properties of the AlSi9Mg Alloy With Exothermical Modifier. MANUFACTURING TECHNOLOGY, 2011, vol. 11, p. 44-49. ISSN 1213-2489

[8] KRŇÁVEK, V.; STŘÍTECKÝ, F. (2007). Konstrukce forem pro odlitky lité pod tlakem a její vliv na výskyt vad. Slévárenství č. 2-3, 2007, s. 81-86

[9] EPERJEŠI, L', MALIK, J., EPERJEŠ, Š., FECKO, D. (2013). Influence of returning material on porosity of die castings. MANUFACTURING TECHNOLOGY, 2013, vol. 13, no. 1, p. 36-39. ISSN 1213-2489

[10] BOLIBRUCHOVÁ, D., RICHTÁRECH, L. (2013). Study of the gas content in aluminum alloys. MANUFACTURING TECHNOLOGY, 2013, vol. 13, no. 1, p. 14-20. ISSN 1213-2489

[11] GREGER, M., WIDOMSKÁ, M. (2011). Analysis of influence of structure on mechanical properties of AlSiMg aluminium alloy processed by ECAP. MANUFACTURING TECHNOLOGY, 2011, vol. 11, p. 17-22. ISSN 1213-2489

[12] PAŠKO, J., GAŠPÁR, Š. (2013). Experimental monitoring of HB hardness and ultimate tensile strenght UTS of pressure of Al-Si castings depending on the increase pressure changes. In: Advanced Materials Research, Vol. 711, 2013, p. 272-275, ISSN 1022-6680

[13] GAŠPAR, Š., MAŠČENIK, J., PAŠKO, J. (2012). The effect of degassing pressure castings molds on the quality of pressure castings. In: Advanced Materials Research, Vol. 428, 2012, p. 43 - 46, ISSN 1022-6680 